\title{
Protective effect of combined aqueous extracts of Allium sativum and Zingiber officinale against lead acetate induced hepatotoxicity and testicular damage in Rattus norvegicus
}

\begin{abstract}
Background: Allium sativum and Zingiber officinale are medicinal plants used for the management of ailments/diseases and as culinary spices. Their pharmacological potentials ranges from hepatoprotection, immunomodulation, antimutagenic, antioxidant antibacterial, anticarcinogenic, antifungal, hypoglycemic, hyperglycemic and anti-atherosclerotic. However, their synergistic potentials are not fully reported.

Aim: This study was aimed at evaluating the protective potentials of combined aqueous extracts of Allium sativum and Zingiber officinale against lead acetate induced hepatic and testicular damage.

Materials and methods: Albino rats $(\mathrm{n}=50)$ were used for this study. The rats were divided into two major groups; acute studies $(n=20)$ and chronic studies $(n=30)$. The acute study was further subdivided into two phases, low dose and high dose of 12 and 8 rats respectively. Calculated doses of lead acetate in $\mathrm{mg}$ per kg body weight was given at various concentration of $500 \mathrm{mg} / \mathrm{kg}, 700 \mathrm{mg} / \mathrm{kg}$ (low dose) and $4000 \mathrm{mg} / \mathrm{kg}, 5000 \mathrm{mg}$ / $\mathrm{kg}$ and $6000 \mathrm{mg} / \mathrm{kg}$ (high dose) to determine the LD50. Signs of toxicity and mortality were observed eight hourly and at 24 hours interval. Chronic study $(n=30)$ were further subdivided into 5 (five) groups each containing six (6) animals. Group A received $2 \mathrm{ml} / \mathrm{kg}$ distilled water and normal feed, Group B (disease control), C, D and E received $2 \mathrm{mls}$ of $5000 \mathrm{mg} / \mathrm{kg}$ body weight of lead acetate only once after $24 \mathrm{hr}$ of starvation, while Group C, $\mathrm{D}$ and $\mathrm{E}$ were treated (post $72 \mathrm{hrs}$ after administration) with $2 \mathrm{ml}$ of $1000 \mathrm{mg} / \mathrm{kg}$ body weight of aqueous extract extracts of Allium sativum, Zingiber officinale and combined extracts of Zingiber officinale and Allium sativum for 4weeks respectively.
\end{abstract}

Results: Writhing, sedation, swirling, diarrhoea and death were observed at $5000 \mathrm{mg} / \mathrm{kg}$ and was established as the LD50. Lead acetate induces centrolobular hepatic necrosis and hypertrophy of the seminiferous tubules as revealed by heamatoxylin and eosin stained slides and also elevation of blood Lead level (BLL). Treatment with Allium sativum and Zingiber officinale (combined extracts) showed a statistically significant reduction in blood lead level $(\mathrm{t}=12.0, \mathrm{p}=0.01)$, and restoration of the hepatic and testicular cytoarchitecture compared to when administered independently.

Conclusion: The study revealed that the synergistic effect of Allium sativum and Zingiber officinale is capable of ameliorating lead acetate induced hepatic and testicular damage as well as reduction of blood lead level in the rats. This synergistic potential may be an excellent reservoir of pharmaceutical and chemical templates for new drugs formulation to be explored.
Volume 5 Issue 5 - 2018

Yibala I Oboma,' Beredugo Sylvanus,' Prudence N Okara, I Favour A Tamunoomie,' Okama Eko lbiang²

'Department of Medical Laboratory Sciences, Faculty of Basic Medical Sciences, Niger Delta University, Nigeria

${ }^{2}$ Department of Community Health, College of Health Technology, Calabar, Nigeria

Correspondence: Yibala I Oboma, Department of Medical Laboratory Science, Faculty of Basic Medical Sciences, College of Health Sciences, Niger Delta University, Wilberforce Island, Bayelsa State, Nigeria, Email:yoboma78@gmail.com

Received: August 01, 2018 | Published: October 02, 2018

Keywords: testicular toxicity, hepatotoxicity, Allium sativum, Zingiber officinale

\section{Introduction}

Lead has been described as one of the most toxic metals in our environment. ${ }^{1}$ It also forms part of a group of metals described as carcinogenic in humans Its carcinogenic potential is considered to be dependent on the metal's oxidation state, solubility and complex formation. ${ }^{2}$ Due to increasing anthropogenic activities and vehicular emissions, it has been indicated that the amount of lead available in the environment for potential consumption via food chains and drinking water supplies is on the rise. ${ }^{2}$ Lead poisoning is also a global health problem but it is unrecognized as such in a number of African countries. Lead poisoning as indicated by elevated blood lead levels
(BLL) have been observed in the general population in some parts of Nigeria. ${ }^{3}$ In adults, occupational exposure to lead is the most common cause of lead poisoning with a wide range of physiological, biochemical, behavioural and organ dysfunctions mostly the kidney, liver, spleen and testes. ${ }^{3}$ In 2013, lead was believed to have resulted in 853,000 deaths, which occurred mostly in the developing countries with the poor been at greater risk. ${ }^{4}$ Descriptions of lead poisoning is dated to at least 2000 BC. . $^{5,6}$

Health benefits of Allium sativum (garlic) in lipid regulation, anticarcinogenic, antimicrobial and antioxidant potentials has been extensively reported in previous studies ${ }^{7,8}$ while Zingiber officinale 
ginger is arguably one of the most widely used culinary agent and spice in the world. ${ }^{9,10}$ Phytochemical studies have shown that the unique culinary and medicinal properties of ginger are due to the presence of phytochemicals like zingerone, shogaols, ingerols, pardols, $\beta$-phellandrene, curcumene, cineole, geranyl acetate, terphineol, terpenes, borneol, geraniol, limonene, $\beta$-elemene, zingiberol, linalool, $\alpha$-zingiberene, $\beta$-sesquiphellandrene, $\beta$-bisabolene, zingiberenol and $\alpha$-farmesene. ${ }^{9,11,12}$ Scientific studies carried out in accordance with the principles of modern systems of medicine have convincingly shown that ginger possesses numerous health benefits like antimicrobial, antiviral, gastroprotective, antidiabetic, anti-hypertensive, cardioprotective, anticancer and immunomodulatory effects. ${ }^{9,11}$ Additionally, preclinical studies carried out with laboratory animals have also shown that ginger possesses hepatoprotective constituents, and can protect the liver against the toxic effects of diverse class of xenobiotic agents like alcohol ${ }^{13,14}$ acetaminophen, ${ }^{15}$ heavy metals ${ }^{16-18}$ bromobenzene and lead. ${ }^{19}$ Several plant species serve as excellent reservoirs of pharmaceutical and chemical templates for new drugs formulation. It is against this background that this study was designed to investigate the protective effects of Allium sativum and Zingiber officinale on lead induced toxicity on the testes and liver of Rattus norvegicus rats.

\section{Materials and methods}

\section{Experimental animal care and design}

Fifty healthy rats of average weight (149-179g) were purchased from the animal house of the Department of Pharmaceutical Sciences, University of Port Harcourt, Rivers State. The animals were randomly divided into two major groups; 20 for acute studies and 30 for chronic studies and housed in cages made of metal nesting and were fed with growers mash and distilled water with 12 hours light and dark cycle. The beddings were changed and the cages cleaned every morning and disinfected at interval of three days. The rats were allowed to acclimatize for 14 days before experimentation.

\section{Acute and chronic toxicity study and experimental design}

The rats for acute study were divided into two phases. Phase one (low dose) and phase two (high dose) of 12 and 8 animals respectively. Calculated dose of lead acetate in $\mathrm{mg}$ per $\mathrm{kg}$ body weight was given to the rats at various concentration of $500 \mathrm{mg} / \mathrm{kg}, 700 \mathrm{mg} / \mathrm{kg}$ (phase one), and $4000 \mathrm{mg} / \mathrm{kg}, 5000 \mathrm{mg} / \mathrm{kg}$ and $6000 \mathrm{mg} / \mathrm{kg}$ in phase two. Signs of toxicity and mortality were observed eight hourly and $24 \mathrm{hrs}$ interval. Thirty (30) animals were used for chronic study: Five groups each n= 6 rats: Group A (negative control) received $2 \mathrm{ml} / \mathrm{kg}$ water and normal feed. Group B (disease control), C, D and E received $5000 \mathrm{mg} / \mathrm{kg}$ body weight of lead acetate only once after $24 \mathrm{hrs}$ of starvation. Group C, $\mathrm{D}$ and $\mathrm{E}$ were treated (post $72 \mathrm{hrs}$ after exposure to lead acetate) with $2 \mathrm{ml}$ of $1000 \mathrm{mg} / \mathrm{kg}$ body weight of aqueous extracts of Allium sativum, Zingiber officinale and combined extracts of Zingiber officinale and Allium sativum for 4 weeks respectively.

\section{Extracts and lead acetate preparation}

The Zingiber officinale rhizome was purchased in Yenagoa, Bayelsa State. The fresh ginger rhizomes was washed, cleaned, peeled, cut into pieces and dried by hot air oven at $60^{\circ} \mathrm{C}$. It was then crushed to fine powder using Electroline blender (Model: CM/L 7962804, China). The aqueous extract was prepared in accordance with the method of Hitesh et al. ${ }^{20} 500 \mathrm{~g}$ of the fine powder was homogenized in $750 \mathrm{ml}$ of distilled water and $250 \mathrm{ml}$ of ice cold water for 12 minutes.
The homogenized mixture was filtered using cheese cloth. The filtrate was centrifuged using macro centrifuge at $2500 \mathrm{rpm}$ for $10 \mathrm{mins}$, the clear supernatant separated and the volume made up to $1000 \mathrm{ml}$ with distilled water. The concentration was regarded as stock $(500 \mathrm{~g} / \mathrm{ml})$ based on the weight of the Zingiber officinale extract. The aqueous extract of Allium sativum was prepared in accordance with the method of Mathew et al. ${ }^{41} 500 \mathrm{~g}$ of Allium sativum bulbs were crushed and added to $100 \mathrm{ml}$ of distilled water. The juice was extracted using an Electroline blender (model no CM/L 7962804, China). The mixture was filtered thrice using cheese cloth and then centrifuged using macro centrifuge at $2500 \mathrm{rpm}$ for $10 \mathrm{mins}$. The supernatant was transferred to a clean bottle and stored at $2-8^{\circ} \mathrm{C}$ until use. The concentration was considered $500 \mathrm{~g}$ based on the weight of the paste $/ \mathrm{ml}$. Equal volume of both extracts was regarded as supplement and thus served the animals for the period of experiment.

About $5000 \mathrm{mg}$ of lead acetate powder was weighed using Medfield electronic balance and dissolved into $500 \mathrm{mls}$ of distilled water and made up to $1000 \mathrm{ml}$. The mixture was stirred using a glass rod until it was completely dissolved.

\section{Extract administration and sub-acute toxicity study}

The administered dose was calculated from the stock lead acetate and given as milligram per kilogram body weight. $2 \mathrm{ml}$ of the extract was administered orally once a day using metal cannula attached to $2.0 \mathrm{ml}$ syringe and lasted for 4 weeks. All the groups were pre exposed to $5000 \mathrm{mg}$ per kilogram body weight of lead acetate except control group. The animals were deprived of food and water for $24 \mathrm{hrs}$ before administration of the supplement and thereafter allowed access to food. The study was conducted in accordance with the Institute of Health guide for the care and use of laboratory animals 32 as well that of Niger Delta University, Wilberforce Island Bayelsa State.

After 4 weeks of treatment with extracts, the Rattus norvegicus were anaesthetized using light dose of diethyl-ether prior to sacrifice and blood samples collected by cardiac puncture using needle and syringe. Blood samples were transferred immediately to lithium heparin container while the tissues collected were fixed immediately in $10 \%$ formal saline for histopathological analysis.

\section{Determination of blood leads level (BLL) and histopathology}

Determination of blood lead level was by lead digestion method. About $5 \mathrm{ml}$ of concentrated $\mathrm{HNO}_{3}$ and $10 \mathrm{ml}$ of concentrated $\mathrm{H}_{2} \mathrm{SO}_{4}$ was added to the blood sample gently and carefully. The mixture was heated and cooled intermittently, discharging brown fumes of nitric oxide. Again $5 \mathrm{ml}$ of concentrated $\mathrm{HNO}_{3}$ was added and reheated until the solution was clear. It was then made up to $50 \mathrm{ml}$ with distilled water and filtered using cotton wool to remove filtrate. The level of lead $(\mathrm{Pb})$ in $\mu \mathrm{g} / \mathrm{dl}$ in the blood was determined by atomic absorption spectrophotometer at $217 \mathrm{~nm}$ wavelength.

The principle of reaction was based on the chemical theory of dye, where the acidic and basic dyes stain the basic and acidic components of the tissue respectively. Heamatoxylin is a basic stain which stains the nucleus which is acidic while eosin is an acidic stain that counter stains the cytoplasm which is basic giving a pink color. Tissue processing was in accordance with standard histological processing schedule by Aviwioro et al. ${ }^{21}$ The tissues were sectioned at $4 \mu \mathrm{m}$ using rotary microtome and were stained by Erhlich's heamatoxylin and Eosin. Photomicrographs of the stained tissue sections were produced using a digital microscope (Olympus ${ }^{\circledR}$ ) at x 400 magnification. 


\section{Results}

\section{Acute study}

The animals were observed continuously for one hr after administration of lead acetate and hourly intervals for eight hrs then after $24 \mathrm{hrs}$ for signs of toxicity such as behavioral changes and mortality. In Phase 1; only behavioral changes was observed while in Phase 2, both behavioral changes and mortality was observed. LD50 was estimated as a cut-off value since no mortality occurred even at values above $5000 \mathrm{mg} / \mathrm{kg}$.

\section{Weight changes}

Testis: Acute toxicological study of different concentration of lead acetate on rats revealed increase in the weight of the testis from lower concentration to higher concentration as shown in Table $1 \&$ Table 2.The substance is suspected to have induced testicular hypertrophy in the rats. Following aqueous extracts administration, apart from the group B that had only lead $(1.09 \pm 0.271)$ the rats recorded reduction in testicular weight compared with control $(1.21 \pm 0.40)$. Whereas, there was increase in testicular weight in groups $(\mathrm{C}$ and $\mathrm{D})$ that received Allium sativum and Zingiber officinale extracts respectively. In Group E $(1.21 \pm 0.60)$ rats that received combination of both extracts showed testicular mean weight similar to the control group indicating a protective effect.

Liver: Acute toxicological study of different concentrations of lead acetate clearly reveals a reduction in the weight of the rat's liver displaying a classical reduction in organ weight from $6.40 \pm 0.23$ in $500 \mathrm{mg} / \mathrm{kg}$ concentration to $5.86 \pm 0.08$ in $4000 \mathrm{mg} / \mathrm{kg}$ and a drastic reduction of weight at highest concentration of $5000 \mathrm{mg} / \mathrm{kg}(1.47 \pm 0.47)$. There was hypertrophy of the liver following lead inducement and subsequent treatment with Allium sativum, and Zingiber officinale extracts to groups B, C, D and E respectively, compared with control group (group A). The liver of group B compared with group A (5.32 \pm 0.64 vs. $4.73 \pm 0.33)$ showed an increase in liver weight. The combine hepatoprotective effect of Allium sativum and Zingiber officinale extracts $(5.32 \pm 0.64$ vs. $5.10 \pm 0.59)$ was higher compared with Allium sativum (5.32 \pm 0.64 vs. $5.47 \pm 0.82$ ) and Zingiber officinale $(5.32 \pm 0.64$ vs. $5.20 \pm 0.05)$ administered independently. The analysis of Variance (ANOVA) of difference in weight among the groups showed a non-statistically significant relationship as well as the post hoc analysis using Turkey method of comparison of variance. Generally, there was statistically significant increase $(\mathrm{P} \leq 0.05)$ in the mean body weight of rats in all the groups as presented in Table 3 .

Table I LD50,5000mg/kg; numerator, number of rats affected; Denominator, number of animal tested

\begin{tabular}{lllllll}
\hline & Dose & Writhing & Sedation & Swirling & Diarrhoea & Death \\
\hline Phase I & Control & $0 / 4$ & $0 / 4$ & $0 / 4$ & $0 / 4$ & $0 / 4$ \\
& $500 \mathrm{mg} / \mathrm{kg}$ & $0 / 4$ & $0 / 4$ & $0 / 4$ & $0 / 4$ & $0 / 4$ \\
& $700 \mathrm{mg} / \mathrm{kg}$ & $2 / 4$ & $1 / 4$ & $0 / 4$ & $0 / 4$ & $0 / 4$ \\
Phase 2 & Control & $0 / 2$ & $0 / 2$ & $0 / 2$ & $0 / 2$ & $0 / 2$ \\
& $4000 \mathrm{mg} / \mathrm{kg}$ & $1 / 2$ & $1 / 2$ & $0 / 2$ & $1 / 2$ & $0 / 2$ \\
& $5000 \mathrm{mg} / \mathrm{kg}$ & $2 / 2$ & $2 / 2$ & $2 / 2$ & $2 / 2$ & $2 / 2$ \\
& $6000 \mathrm{mg} / \mathrm{kg}$ & $2 / 2$ & $2 / 2$ & $2 / 2$ & $1 / 2$ & $2 / 2$ \\
\hline
\end{tabular}

Table 2 Acute toxicological study of oral administration of lead acetate on organs weight (testis and liver) of Rattus norvegicus

\begin{tabular}{|c|c|c|c|c|}
\hline \multirow{2}{*}{$\begin{array}{l}\text { Organ } \\
\text { weight }\end{array}$} & \multicolumn{4}{|c|}{ Concentration of lead acetate } \\
\hline & $500 \mathrm{mg} / \mathrm{kg}$ & $700 \mathrm{mg} / \mathrm{kg}$ & $4000 \mathrm{mg} / \mathrm{kg}$ & $5000 \mathrm{mg} / \mathrm{kg}$ \\
\hline $\begin{array}{l}\text { Testis } \\
(1.21 \pm 0.40)\end{array}$ & $2.06 \pm 0.01$ & 2. $07 \pm 0.0 \mathrm{I}$ & $2.08 \pm 0.02$ & $2.04 \pm 0.05$ \\
\hline $\begin{array}{l}\text { Liver } \\
(4.73 \pm 0.33)\end{array}$ & $6.40 \pm 0.23$ & $5.47 \pm 0.34$ & $5.86 \pm 0.08$ & $1.47 \pm 0.47$ \\
\hline
\end{tabular}

Values expressed as Mean $\pm \mathrm{SD}, \mathrm{Kg}$, kilogram; mg, milligram

Table 3 Evaluation of the effect of aqueous extracts on blood lead level of Rattus norvegicus using mass absorption spectrophotometric assay

\begin{tabular}{llllll}
\hline Variable & Mean & SEM & t-test & $\mathbf{P}<0.05$ & comment \\
\hline Group B & 0.44 & 0.03 & & & \\
Group C & 0.39 & 0.09 & 0.43 & 0.33 & $\mathrm{NS}$ \\
Group D & 0.63 & 0.03 & 3.7 & 0.01 & $\mathrm{~S}$ \\
Group E & 0.03 & 0.01 & 12 & 0.01 & $\mathrm{~S}$
\end{tabular}

SEM, standard error of mean; S, significant at $\mathrm{P}<0.05$; NS, non-significant

Group B, lead administered group only

Group C, Lead acetate and Allium sativum administered group

Group D, Lead acetate and Zingiber officinale administered group

Group E, Lead acetate with Allium sativum+Zingiber officinale administered group

\section{Effect of combined extracts on blood lead level (BLL) and histological examination}

Table 3 shows the effect of combined extracts on blood lead level on lead induced Rattus norvegicus. There was a decrease in blood lead concentration in Rattus norvegicus administered with Allium sativum (group C) post lead induced poisoning ( $0.44 \pm 0.03$ vs. $0.39 \pm 0.09)$. There was equally a statistically significant reduction in blood lead level following oral administration of Zingiber officinale. However, group E showed a drastic reduction in blood lead level after administration of Allium sativum and Zingiber officinale combined for 4 weeks $(0.44 \pm 0.33$ vs. $0.03 \pm 0.01)$ and was statistically significant at $\mathrm{t}=12.0$ and $\mathrm{P}=0.01$. (Figure $1 \&$ Figure 2)

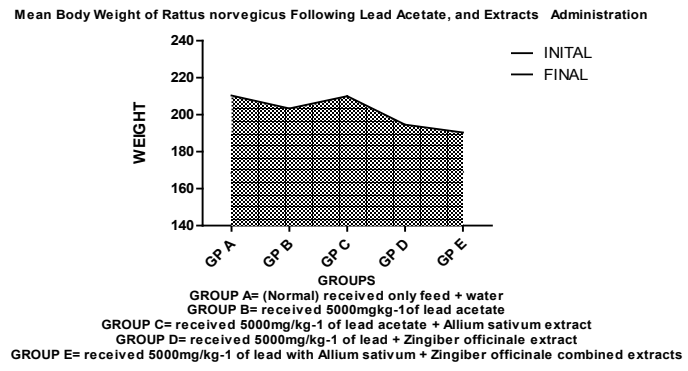

Figure I Mean body weight of Rattus norvegius following lead acetate and extracts administartion. 


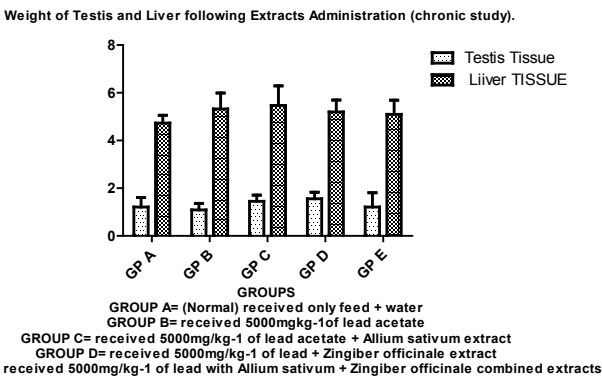

Figure 2 Weight of testis and liver following extracts administration (chronic study).

Light microscopy examination of Haematoxylin and Eosin stained representative sections of testicuar tissues and liver tissue as presented in Figure 3 \& Figure 4 showed the normal control rat's liver showing a central vein with normal sinusoids and normal space of Disse. The hepatocytes are normal, all suggestive of normal liver tissue architecture. Likewise, representative sections of testicular tissue from negative control (normal) indicates normal seminiferous tubules containing different types of germ cells; spermatogonia lying on the basement membrane beneath which are the myofibroblasts, spermatocytes, spermatids and spermatozoa. The interstitial tissues found between seminiferous tubules contain interstitial cells and Leydig Cells. Liver tissue section intoxicated with $2 \mathrm{mls}$ of $5000 \mathrm{mg}$ per kilogram body weight of lead acetate to induce hepatotoxicity shows inflammatory cells filling the portal and spilling over the surrounding parenchyma. There is also distortion of the space of Disse. The substance is hepatotoxic at that concentration, duration and route of administration. In the same manner, histology of testicular tissue of rats administered with $2 \mathrm{ml}$ of $5000 \mathrm{mg} / \mathrm{kg}$ per body weight of lead acetate solution shows hypertrophy of the seminiferous tubules with increase in tubular diameter

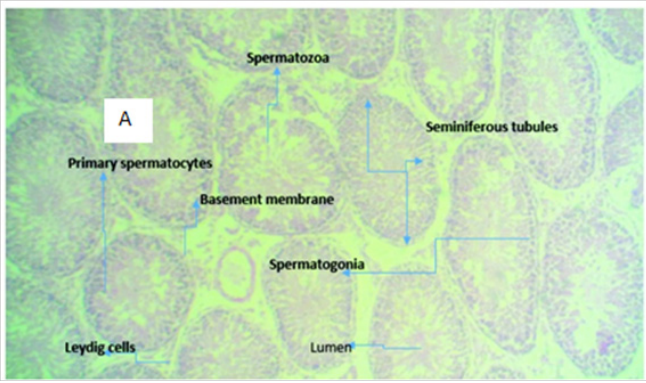

(A) (Control): micrograph of testicular tissue showing normal histomorphology of the testis (normal seminiferous tubules, spermatogonia, spermatocyte).

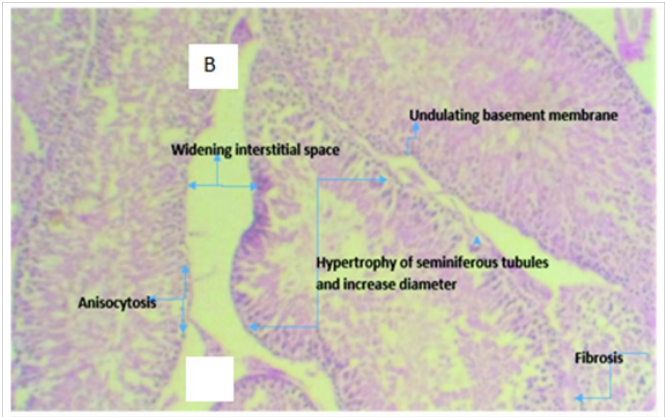

(B) Micrograph of testicular tissue from rat intoxicated with $2 \mathrm{ml}$ of $5000 \mathrm{mg} /$ $\mathrm{kg}$ of lead acetate solution showing hypertrophy of the seminiferous tubules with increase tubular diameter which demonstrates the tissue toxicity potentials of lead acetate.

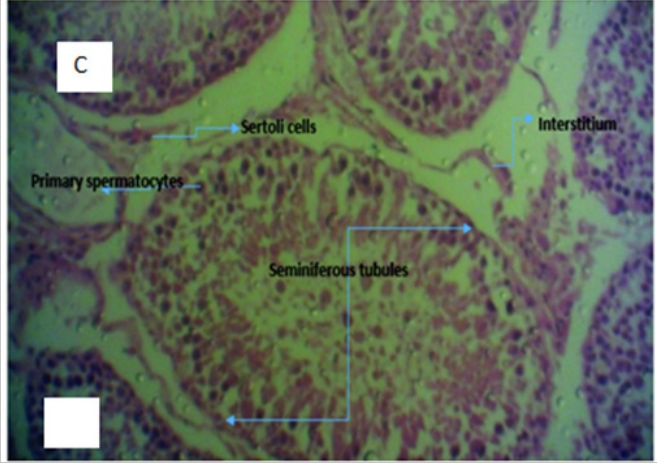

(C) Micrograph of testicular tissue from rats administered with $2 \mathrm{ml}$ of $5000 \mathrm{mg} / \mathrm{kg}$ of lead acetate and garlic (Allium sativum) for 4 weeks showing normal testicular tissue with evidence of tissue regeneration and proliferation

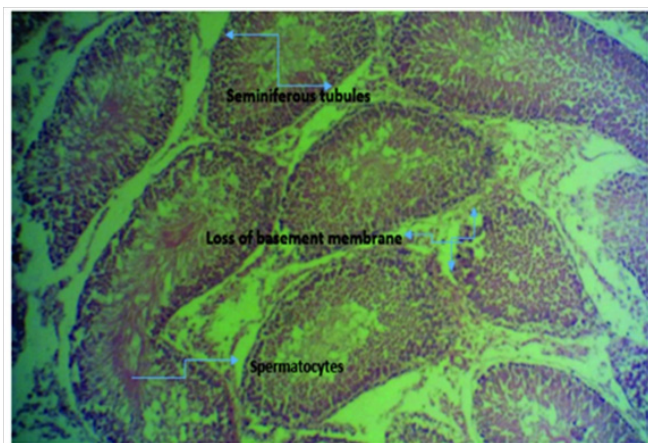

(D) Micrograph of tissue from rat's testis induced with $2 \mathrm{ml} \mathrm{of} 5000 \mathrm{mg} / \mathrm{kg}$ lead acetate and then administered with aqueous extract of ginger (Zingiber officinale) for 4 weeks showing normal seminiferous tubules and its features. There is also degeneration of the tubules at some point with loss of basement membrane. Substance showed low protection against lead poisoning

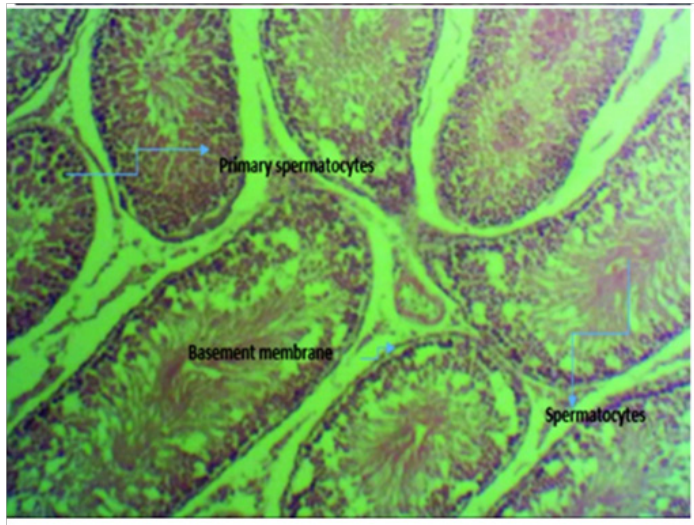

(E) micrograph of rats induced with $2 \mathrm{ml}$ of $5000 \mathrm{mg} / \mathrm{kg}$ lead acetate poisoning and then administered with equal mixture of aqueous extract of ginger and garlic (Zingiber officinale and Allium sativum) combined for 4 weeks showing normal seminiferous tubules with intact basement membrane housing the spermatogonia cells and proliferating spermatocytes and healthy spermatids with prominent spermatocytes compared to those induced with lead without treatment.

Figure 3 Photomicrographs of testicular tissue sections of Rattus norvegicus stained with $\mathrm{H} \& \mathrm{E}$, with $\times 400$ magnification.

Hepatocytes induced with $2 \mathrm{mls}$ for $24 \mathrm{hrs}$ with $5000 \mathrm{mg}$ per kilogram body weight of lead acetate solution and then treated with $2 \mathrm{mls}$ of aqueous solution of Allium Sativum for 4 weeks shows centrolobular necrosis (Figure 2), swollen hepatocytes, central vein and the surrounding hepatocytes at some point appear unremarkable and filled with inflammatory cells (Figure 2; Group H2). From 
the histology result, it is obvious that Allium sativum alone has no hepatoprotective potentials against lead acetate induced liver poisoning. Also, group of rats induced with lead acetate poisoning and then administered with aqueous garlic extract (Allium sativum) for 4 weeks shows normal testicular tissue with evidence of tissue regeneration and proliferation. This evidence suggests that Allium sativum is more testicular protective than hepatocytes protective.

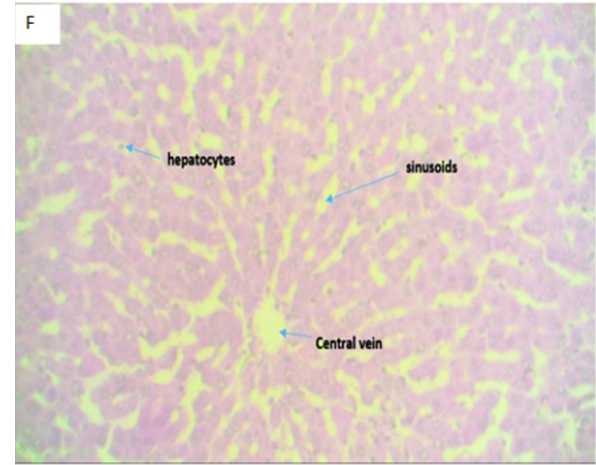

F (Control): Micrograph of normal liver tissue displaying a central vein with normal sinusoids and space of Disse. The hepatocytes appear normal, suggestive of a normal liver tissue.

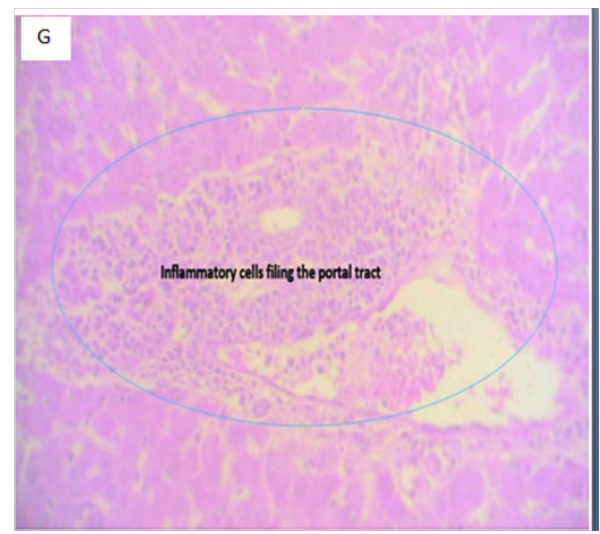

(G) Micrograph of liver tissue of Rattus norvegicus induced with $2 \mathrm{mls}$ for 24 hrs of $5000 \mathrm{mg} / \mathrm{kg}$ body of lead acetate solution showing inflammatory cells filling the portal tract; indicative of lead acetate induced tissue insult.

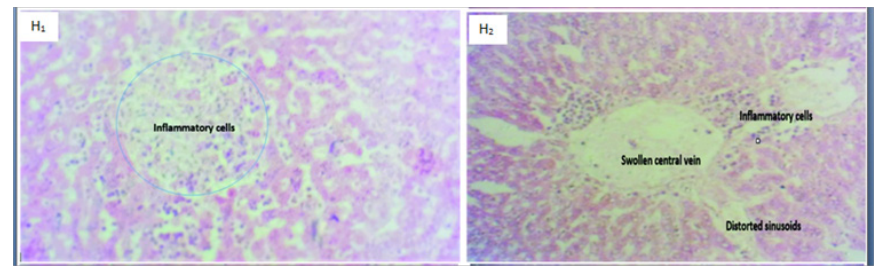

(HI\& H2): Micrograph of a liver tissue of Rattus norvegicus induced with $2 \mathrm{mls}$ ( 3 doses) for $24 \mathrm{hrs}$ with $5000 \mathrm{mg} / \mathrm{kg}$ body weight of lead acetate solution and then $2 \mathrm{mls}$ of aqueous solution of Allium Sativum for 4 weeks showing Centro lobular necrosis $(\mathrm{HI})$, swollen hepatocytes, central vein and inflammatory cells $(\mathrm{H} 2)$. The histology result reveals that Allium sativum has no hepatocytes protection against lead acetate induced liver poisoning.

Liver and testicular tissue of Rattus norvegicus treated with $2 \mathrm{mls}$ of aqueous solution of Zingiber officinale for 4 weeks showed necrotic cells (acidophilic bodies) seen as homogenous pinkish structure. Seen also were swollen hepatocytes, sinusoids, presence of mitotic figures and fatty cells. The presence of mitotic figures is suggestive of ongoing reparative process (hepato-regeneration). In a nutshell, ginger has mild hepatocyte protection against lead induced hepatocyte poisoning. Histological picture of testis reveals normal seminiferous tubules and its features. There is also degeneration of the tubules at some point with loss of basement membrane. Substance showed low protection of testicular tissue against lead poisoning.

(I) Micrograph of liver tissue of Rattus norvegicus induced with $2 \mathrm{mls}$ of $5000 \mathrm{mg} /$

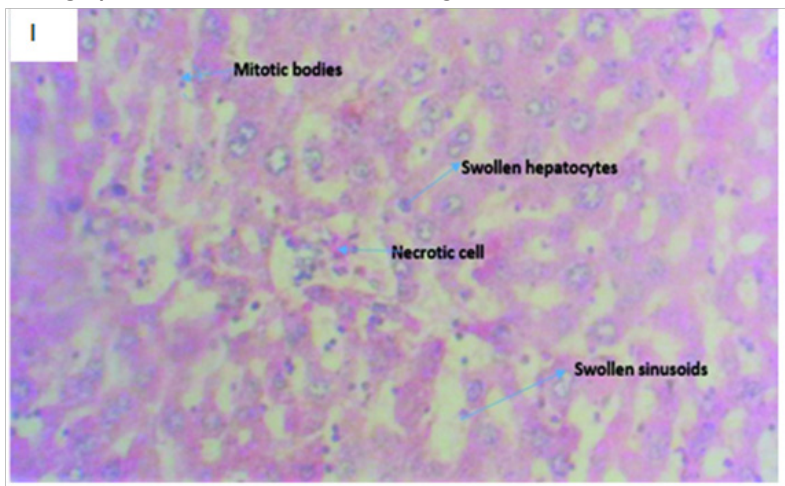

$\mathrm{kg}$ of lead acetate solution for $24 \mathrm{hrs}$ and then $2 \mathrm{mls}$ of aqueous solution of Zingiber officinale for 4 weeks showing necrotic cells (acidophilic bodies) appearing as homogenous pinkish structure; swollen hepatocytes, sinusoids and presence of mitotic bodies and fatty cells. The presence of mitotic bodies is suggestive of the reparative and hepatoprotective potentials of ginger.

(J) Micrograph of liver tissue section of Rattus norvegicus induced with $2 \mathrm{mls}$

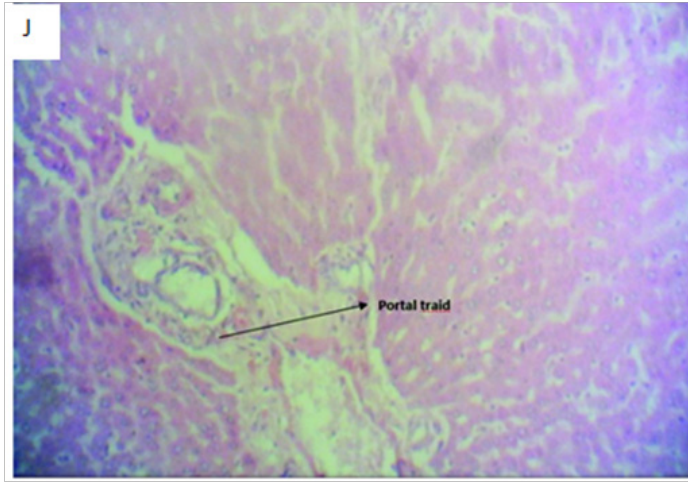

of $5000 \mathrm{mg} / \mathrm{kg}$ of lead acetate solution for 24 hours and then treated with $2 \mathrm{mls}$ of aqueous solution of Allium sativum and Zingiber officinale combined (I:I) for 4 weeks showing well differentiated liver section with a portal tract with normal morphology and few inflammatory cells. The sinusoid and space of Disse is normal with normal hepatocytes compared to the control. The combination of Allium sativum and Zingiber officinale shows hepatoprotective activities against lead acetate induced liver poisoning.

Figure 4 Photomicrographs of H\&E stained liver tissue sections with $\times 400$ magnification.

Liver and testicular tissue of Rattus norvegicus induced with $2 \mathrm{mls}$ ( 3 doses) for 24 hours with $5000 \mathrm{mg}$ per kilogram body weight of lead acetate solution and then $2 \mathrm{mls}$ of aqueous solution of Allium sativum and Zingiber officinale combined (1:1) for 4 weeks shows well differentiated liver section with a portal tract with normal morphology and few inflammatory cells. The sinusoid and space of Disse is normal with normal hepatocytes compared to the control. Thus the combination of Allium sativum and Zingiber officinale shows hepatoprotective activities against lead acetate induced liver poisoning. While, histology of testicular tissue shows normal seminiferous tubules with intact basement membrane housing the spermatogonia cells and proliferating spermatocytes and healthy spermatids with prominent spermatocytes compared with those on lead only.

\section{Discussion}

The use of medicinal herbs and plants in the management of 
ailments and diseases is dated back to antiquity. Result oriented biological and pharmacological properties have long been explored in Allium and Zingiber genera most notably; Allium sativum and Zingiber officinale species. Spermatogenesis is a complex process where clinical and pathological manifestations affect fertility. Due to high concentration of polyunsaturated fatty acids within the plasma membrane of free radicals; high levels of it can damage the membrane of spermatozoa which in turn impairs motility of the semen and overall spermatogenesis. ${ }^{11,22}$ Our results shows that lead acetate is toxic to rat's testis cytoarchitecture as it induces hypertrophy of the seminiferous tubules, widening of the interstitial space thus impairing Leydig cells growth; and this is in agreement with previous studies on the effect of lead on testicular tissues.

Lead was reported to have a cytotoxic effect on the interstitial Leydig cells which secrete testosterone and inhibits the expression of certain enzymes involved in the biosynthesis of steroid hormones. ${ }^{23}$ Hypertrophy of the seminiferous tubules in group of rats administered with lead acetate was reported in the present study. However, AlOmar et al..$^{24}$ and Corpas et al. ${ }^{25}$ reported that lead causes decrease in seminiferous tubules diameter as well as thickness in adult rats. Garu et al. ${ }^{26}$ also observed that different doses of lead impaired the development of various components of the testis and decreases the size of the tubules which is in agreement with the current study that have reported a decrease in testicular weight in rats that received only lead acetate. It is imperative to critically monitor drug-induced changes in animal weight which is an indicator of drug effect according to Nwidu et al. ${ }^{27}$ Allium sativum is considered as a protective regime for different tissues against arsenic induced toxicity and has also proved a protective role against testis and spermatogenesis damages in lead intoxicated rats. ${ }^{28}$ This is in agreement with the present study that has reported testicular cytoarchitecture restoration in rats treated with extracts. Such protection may reduce lipid peroxidation and increase antioxidant defense mechanism. Kamtchouing et al. ${ }^{29}$ observed an increase in testicular weight after 8 days of garlic administration attributable to gingerol in garlic, while Garu et al. ${ }^{26}$ observed significant decrease in testicular weight and seminiferous tubular diameter.

Zingiber officinale (ginger) has shown beneficial effects on male reproductive functions as observed in adult male rats; evidenced by the normal seminiferous tubules, spermatozoa and basement membrane and increase testicular weight following the administration of Zingiber officinale in the present study. The increase testicular weight could be traced to increase in androgen biosynthesis. Androgen has shown to be important for the development, growth and normal functioning of the testis. Khaki et al. ${ }^{22}$ also proven that ginger treatment resulted in increased testicular weight, and increased serum testosterone levels in Wistar rats thus, demonstrating the antioxidant and androgenic properties of ginger. According to Jedlinska-Krakowska et al. ${ }^{30}$ a couple of research have come up with evidence that diet containing vitamins A, B, C, E and antioxidants are capable of increasing the stability or integrity of the blood testis barrier thus; concealing the sperm DNA (deoxyribonucleic acid) from being attacked by free radicals.

Lead induced tissue toxicity was not only restricted to testicular tissue only but also causes hepatotoxicity as evidenced in this study. Previous reports have shown the liver to be the largest repository of lead among soft tissues followed by the kidney. ${ }^{31}$ The present study observed massive recruitment of inflammatory cells filling the portal tract, swollen hepatocyte and sinusoids following lead inducement. This is in agreement with previous work by Verheij et al. ${ }^{32}$ which reported the accumulation of significant amounts of lead in the liver resulting in oxidative stress with resultant hepatotoxicity. This study also observed hepatocyte proliferation, fatty changes, hydropic degeneration, and necrosis of the hepatocytes, mild fibrosis and biliary hyperplasia. Dongre et al..$^{33}$ proposed that two main factors that contribute to toxicological effects of lead are concentration and duration. This present study also observed a concentration dependent effect of lead toxicity and therefore align with the report of Dongre et al. ${ }^{33}$ Also, lead induced toxicity in the present study revealed the presence of acidophilic bodies seen as homogenous pinkish structures within the necrotic hepatocytes. This may be due to apoptotic alteration, followed by organelles swelling especially in the mitochondria, endoplasmic reticulum and rupture of lysosomes leading to the amorphous eosinophilic cytoplasm as an initial sign in the sequence of hepatocytes necrosis before shrinking and dissolution of nuclei. ${ }^{34}$ In this present study, the effect of lead acetate on body weight gain was assessed and the final body weight of the rats intoxicated with lead only was significantly lower than that of the healthy normal group. The obtained results are in agreement with previous report by Allouche et al. ${ }^{35}$ The decreased body weight may be associated with several factors, one of which is imbalanced metabolism produced by impairing zinc-dependent enzymes which are necessary for many metabolic processes; also lead decreases the level of erythropoietin hormone which has anabolic effect. However, Haouas et al. ${ }^{36}$ attributed the decrease in weight to malabsorption of nutrients from direct toxic effects of lead on the gastrointestinal tract or by inhibition of protein synthesis.

Although, Sankara et al. ${ }^{37}$ has proven that Allium sativum preparations exhibit hepatoprotective properties, this study has a divergent view, based on the histological picture of the liver tissue. In this present study, the hepatoprotective effect of Allium sativum was too minimal to restore the liver morphology despite its significant reduction of blood lead level. Pourjafar et al. ${ }^{38}$ also reported the ability of Allium sativum to reduce the lead levels from the liver, kidney, blood and bone. Also Rodrigo et al. ${ }^{39}$ carried out a study on the curative effect of Allium sativum on alcoholic liver disease subjects and observed that; liver enzymes levels which were increased before Allium sativum administration significantly decreased after Allium sativum treatment..$^{40-42}$ Our results reveal that Zingiber officinale is hepatoprotective and concurs with previous studies carried out with laboratory animals which claim that Zingiber officinale possesses hepatoprotective effects and is in agreement with Khaki et al. ${ }^{22}$ and other previous reports. ${ }^{13,14}$

Zingiber officinale and Allium sativum aqueous extracts combined has shown a substantial anti-inflammatory and hepatoprotective effect compared to when the extracts were administered separately. The combination of both Zingiber officinale and Allium sativum resulted in significant reduction of blood lead level (BLL) compared with the groups administered with either Zingiber officinale or Allium sativum only. This study also observed that; liver tissue in group induced with lead and treated with aqueous extract of Zingiber officinale and Allium sativum showed higher reduction of inflammatory cells and restored to near normal the tissue architecture of liver hepatocytes. ${ }^{43-45}$

\section{Conclusion}

The results of this study has proven that the combination of Zingiber officinale and Allium sativum was able to reverse leadinduced testicular injuries, minimize cytoarchitectural alterations in the testis and ameliorate hepatotoxicity and liver damage. The histomorphology and biochemical changes in the liver as evidenced by histological micrographs and biochemical parameters all showed protective proofs. Although, there is no work that has evaluated 
the combine effect of both extracts apart from this present study; it is our opinion that instead of using Allium sativum or Zingiber officinale alone in the management of lead induced testicular injury or hepatotoxicity; the duo (Zingiber officinale and Allium sativum) should be used as a combine therapy which will be more effective. However, the results obtained from this study provide the platform for further investigation of the promising therapeutic potentials of Zingiber officinale and Allium sativum combined in treatment of testicular and liver damage.

\section{Acknowledgements}

None.

\section{Conflict of interest}

The authors declare that there is no conflict of interest.

\section{References}

1. Patra RC, Rautray AK, Swarup D. Oxidative stress in lead and cadmium toxicity and its amelioration. Vet Med Int. 2011;457327.

2. Koedrith P, Seo YR. Advances in carcinogenic metal toxicity and potential molecular markers. Int J Mol Sci. 2011;12(12):9576-9595.

3. Ademuyiwa O, Aggarwal R, Chandra R, et al. Effects of sub-chronic low-level lead exposure on the homeostasis of copper and zinc in rat tissues. J Trace Elem Med Biol. 2010;24(3):207-211.

4. World Health Organization. Archived from the original on 18 October 2016.

5. Dapul H, Laraque D. Lead poisoning in children. Advances in pediatrics. 2014;61(1):313-333.

6. Needleman H. Lead poisoning. Annual Review of Medicine 2004;55:209-222.

7. Asadaq SM, Inamdar MN. Pharmaco dynamics and pharmacokinetic interactions of propanolol with garlic (Allium sativum) in Rats. Evidence Based Complement Alternative Medicine. 2010:1-11.

8. Ayakeme T, Ibeh GO, Nwinuka MN, et al. Effects of garlic extract on cadmium induced toxicity in wistar albino rat. Indian Journal of Drugs Dispensing. 2012;1:68-73.

9. Balinga MS, Haniadka R, Pereira MM, et al. Update on the chemopreventive effects of ginger and its phytochemicals. Crit Rev Food Sci Nutr. 2011;51(6):499-523.

10. Balinga MS, Haniadka R, Pereira MM, et al. Radioprotective effects of Zingiber officinale roscoe (ginger): past, present and future. Food Funct. 2012;3(7):714-723.

11. Ali BH, Blunden G, Tanira MO, et al. Some phytochemical, pharmacological and toxicological properties of ginger (Zingiber officinale Roscoe): a review of recent research. Food Chem Toxicol. 2008;46(2):409-420.

12. Palatty PL, Haniadka R, Valder B, et al. Ginger in the prevention of nausea and vomiting: a review. Crit Rev Food Sci Nutr. 2013;53(7):659-669

13. Mallikarjuna K, Sahitya CP, Sathyavelu RK, et al. Ethanol toxicity: rehabilitation of hepatic antioxidant defense system with dietary ginger. Fitoterapia. 2008;79(3):174-178.

14. Shati AA, Elsaid FG. Effects of water extracts of thyme (Thymus vulgaris) and Ginger (Zingiber officinale Roscoe) on alcohol abuse. Food Chem Toxicol. 2009;47(8):1945-1949.

15. Ajith TA, Hema U, Aswathy MS. Zingiber officinale Roscoe prevents acetaminophen-induced acute hepatotoxicity by enhancing hepatic antioxidant status. Food Chem Toxicol. 2007;45(11):2267-2272.
16. Khaki AA, Khaki A. Antioxidant effect of ginger to prevent leadinduced liver tissue apoptosis in rat. Journal of Medical Plants Research. 2010;4(14):1492-1495.

17. Vitalis EC, Chukwemeka R, Philippe M E, et al. Effects of Zingiber officinale on liver function of mercuric chloride-induced hepatotoxicity in adult wistar rats. Electron Journal of Biomedics. 2007;3:40-45.

18. Verma RJ, Asnani V. Ginger extract ameliorates paraben induced biochemical changes in liver and kidney of mice. Acta Pol Pharm. 2007;64(3):217-220

19. El-Sharaky AS, Newairy AA, Kamel MA, et al. Protective Effect of ginger extract against bromobenzene-induced hepatotoxicity in male rats. Food Chem Toxicol. 2009;47(7):1584-1590.

20. Hitesh KP Manisha J Bhajat SR, et al. Anthelminitic activity of latex of Jupras cureas (Ratanjot). International Journal of Pharmaceutical Science. 2014;5(3):100-101.

21. Aviwioro O, Owolongba G, Gikin A, et al. Histological techniques and procedure with histological dye extract. International Journal of Medical Science. 2009;1(12):464-466.

22. Khaki A, Fatemeh F, Mohammad N, et al. The effects of Ginger on spermatogenesis and sperm parameters of rat. Iranian Journal of Reproductive Medicine. 2009;7(1):7-12.

23. Gorbel MF, Boujelbene F, Makni-Ayadi F, et al. Impact of lead giving in drinking water on the endocrine and exocrine sexual activity in pubescent rat. Determination of an apoptotic process. Compes Rendus Biologies. 2002;325:927-930

24. Al-Omar MA, Abbas AK, Al-Obaidy SA, et al. Combined effect of exposure to lead and chlordane on the testicular tissues of swiss mice. Toxicology. 2000; 115(1):1-8.

25. Corpas I, Gaspar I, Martinez, S, et al. Testicular alteration in rats due to gestational and early lactational administration of lead. Reprod Toxicol. 1995;9(3):307-313.

26. Garu U, Sharma R, Barber I. Effect of lead toxicity on developing testis of mice. International Journal of Pharmaceutical Sciences and Research. 2011;2(9):2403-2407.

27. Nwidu LL, Ekramy E, Yibala IO, et al. Hepatoprotective and antioxidant activities of Spondias mombin leaf and stem extracts against carbon tetrachloride-induced hepatotoxicity. Journal of Taibah University Medical Sciences. 2018;13(3):262-271.

28. Kiziler AR, Aydemir B, Onaran I, et al. High levels of cadmium and lead in seminal fluid and blood of smoking men are associated with high oxidative stress and damage in infertile subjects. Biol Trace Elem Res. 2007;120(1-3):82-91.

29. Kamtchouing M, Dezfoolian A, Sorooshnia F. Effects of maternal lead acetate exposure during lactation on postnatal development of testis in offspring wistar rats. Iranian Journal of Basic Medical Sciences. 2007;14(2):122-131

30. Jedlinska-Krakowska M, Bomba G, Jakubowski K, et al. Impact of oxidative stress and supplementation with vitamins $\mathrm{E}$ and $\mathrm{C}$ on testes morphology in rats. $J$ Reprod Dev. 2006;52(2):203-209.

31. Mehanna A, Nihal M, Gihan M, et al. Transportation of human umblical cord blood stem cells in rabbits fibrotic liver. Journal of American Science. 2015;8(4):83-94.

32. Verheij JB, de Munnik SA, Dijkhuizen T, et al. An $8.5 \mathrm{Mb}$ overlapping intestinal deletion of $8 \mathrm{q} 24$ in two patients with coloboma, congenital heart defect, limb abnormalities, psychomotor retardation and convulsions. Eur J Med Genet. 2009;52(5):353-357.

33. Dongre NW, Suryakar AN, Patil AJ, et al. Occupational lead exposure in automobile workers in north Karnataka (India): effect on liver and kidney functions. Al Ameen Journal of Medical Sciences. 2010;3(4):284-292. 
34. Pandey G, Seivastava DN, Madhuri S. Standard hepatotoxic model produced by paracetamol in rat. Toxicology International. 2008;15(1):69-70.

35. Allouche L, Haemadouche M, Toaubti A, et al. Effect of long term exposure to low or moderate lead concentrations on growth lipid profile and liver function in albino rats. Advances in biological research 2011;5(6):339-347.

36. Haouas Z, Sallem A, Zidi I, et al. Hepatotoxic effects of lead acetate in rats: histopathological and cytotoxic studies. Journal of Cytology and Histology. 2014;5:256.

37. Sankaran M, Vadivel A, Thangam A. Curative effect of garlic on alcoholic liver disease patients. Jordan Journal of Biological Sciences. 2010;3(4):147-150.

38. Pourjafar M, Aghbolaghi P, Shakhse-Niaie M. Effect of garlic along with lead acetate administration on lead burden of some tissues in mice. Pak J Biol Sci. 2007;10(16):2712-2714.

39. Rodrigo A, Saray Q, Rocio I, et al. Immunodulation and antiinflammatory effects of garlic. Journal of Immunology Research Compound. 2015;2(1)35-39.
40. Ahmad I, Sabir M, Yasin KF, et al. Study of the effects of lead poisoning on the testes in albino rats. Journal of Medical Research. 2010;42:97-101.

41. Matthew BJ, Ahmed N, Gul K, et al. Aged Garlic extract supplemented with $\mathrm{B}$ vitamins, folic acid and-arginine retards the progression of subclinical atherosclerosis a randomized clinical trial. Prev Med. 2014;205(49):101-107.

42. National Institute of Health management of Laboratory Animal Care and Uses. National Institute of Health Publication Number 812385. Washington: Department of Health and Animal Sciences. 1989.

43. Park JH, Bolan N, Meghara M. Bacterial assisted immobilization of lead in soils. Implication for remedy at in pedologist. 2012;162-174

44. Telisman S, Colak B, Pizent A, et al. Reproductive toxicity of low-level lead exposure in metal. Environ Res. 2007;105(2):256-266.

45. Yang HS, Han DK, Kim JR, et al. Effects of alpha-tocopherol on cadmium-induced toxicity in rat testis and spermatogenesis. J Korean Med Sci. 2006;21(3):445-447. 